\title{
Effect of the transport duration time and season on some physicochemical properties of beef meat
}

\author{
Dejan Marenčić1, Ante Ivanković², Vinko Pintić1, Nikolina Kelava² and Tomislav \\ Jakopovićs
}

${ }^{1}$ College of Agriculture at Križevci, Križevci, Croatia, ${ }^{2}$ Department of Animal Production and Technology, Faculty of Agriculture, University of Zagreb, Zagreb, Croatia, ${ }^{3}$ Agrocor d.d., Zagreb, Croatia

\begin{abstract}
The objective of this study was to examine the effect of season and transport time on beef quality. The study was conducted during 12 months of 2009 on 480 bulls and 480 heifers of Simmental breed. The cattle were divided into 2 transport groups and then into 4 season groups according to the journey. Quality indicators $\mathrm{pH}$, electrical conductivity (EC) and meat colour values were measured $24 \mathrm{~h}$ post mortem on $m$. longissimus dorsi. Heifer beef compared to bull beef had better values of quality indicators $(P<0.05)$. Differences in quality indicators were found between cattle slaughtered in the spring and summer seasons and between cattle slaughtered in the autumn and summer seasons $(P<0.05)$. Bull beef had poorer colour, $\mathrm{pH}$ and $\mathrm{EC}$ values in the summer and winter seasons compared to the spring season, whereas heifer beef had poorer $\mathrm{pH}, \mathrm{EC}$ and colour values in the summer period compared to other seasons $(P<0.05)$. In the summer season, poorer $\mathrm{pH}, \mathrm{EC}$ and colour $\left(\mathrm{L}^{*}\right.$ and $\left.\mathrm{h}^{*}\right)$ values were obtained in groups of heifers transported for a longer time compared to heifers transported for a shorter time $(P<0.05)$. In groups of bulls transported for a shorter time during the winter period poorer $\mathrm{pH}, \mathrm{EC}$ and colour values were obtained $(P<0.05)$. This study suggests that the quality of Simmental beef was associated with the season and that environmental factors should be considered when deciding about the time of cattle transport, since this can reduce beef colour in a very short period of time.
\end{abstract}

Keywords: beef, stress, $\mathrm{pH}_{24^{\prime}}$ electrical conductivity, colour

\section{Introduction}

Beef is a very valuable animal product. In recent years, producers have encountered problems with beef distribution, related primarily to frequent occurrence of dark, firm, dry meat (DFD). Consumers place high emphasis on food quality, and their decision on purchasing a product is mainly based on colour. Bright red colours are acceptable and desirable, while dark purple colours create a negative connotation to consumers, who believe that such meat comes from old and sick animals. When cattle are stressed, there is a rapid release of catecholamines (norepinephrine, epinephrine, dopamine), which results in glycogen depletion (Lacourt \& Tarrant 1985) causing a lower rate of post mortem lactic acid synthesis and high ultimate $\mathrm{pH}$. Abnormally high $\mathrm{pH}(>6.0)$ increases the light-absorption and water-binding abilities and results is undesirable colour (Lister 1988). 
During transfer to the slaughterhouse cattle can be exposed to various stressors such as fast or forced movements, exertion, jostling, breakdown of the social group, strange environment, rough treatment (during loading and unloading), novelty, track movement, noise, vibrations, centrifugal force, climatic conditions, shortage of food and water (Grandin 1997, Swanson \& Morrow-Tesch 2001, Broom 2003). Shorter transport may lead to weight reduction, drop in glycogen reserves and increased muscle temperature, which is not always reflected in ultimate $\mathrm{pH}$ (Agnes et al. 1990, María et al. 2003). Prolongation of transport time from the farm to the slaughterhouse has commonly an adverse effect on beef quality but little is known about its direct influence on the texture or colour of beef (Grandin 2000). Transport period to the slaughterhouse is relatively short in some parts of Europe, and in Croatia it is typically less than $6 \mathrm{~h}$.

Further, adverse seasonal conditions can potentially stress meat animals and consequently influence carcass and meat quality characteristics. Cattle are considered more sensitive to hot than to cool temperatures (Baker et al. 1981). During warm weather, cattle show signs of stressful behaviour, impaired physiological functions and increased incidence of morbidity (Hahn \& Mader 1997), while cold weather combined with precipitation increases the rate of body-heat loss and elicits shivering (Smith et al. 1993).

The objective of the present study was to examine the effect of transport time and season on meat quality of Simmental bulls and heifers.

\section{Materials and methods}

Four hundred and eighty Simmental bulls, aged 14-16 months, and four hundred and eighty Simmental heifers, aged 13-15 months, were used in the study during 12 months of 2009. Cattle production system (housing, feeding management and nutritional status) used was the same on both farms. Cattle were kept in large partially shaded multiple pens (approximately 10 cattle in $61 \mathrm{~m}^{2}$ pen) with appropriate feedlot. Bulls and heifers were kept in pens separately. The cattle were fed ad libitum with same diet, based on maize silage and concentrates, and also had ad libitum access to water during whole fattening period. The average nutritional content of the feeds was approximately $7.6 \mathrm{MJ} \mathrm{ME} / \mathrm{kg}$ dry matter and $950 \mathrm{~g}$ crude protein.

Cattle were divided into two transport time groups; the first group included 240 bulls and 240 heifers transported from the farm to the slaughterhouse precisely $92 \mathrm{~min}$ and the second group included 240 bulls and 240 heifers transported from the farm to the slaughterhouse precisely $265 \mathrm{~min}$. Transport times corresponded to approximately $110 \mathrm{~km}$ and $300 \mathrm{~km}$, respectively. Cattle groups were transported unmixed. For each journey, 10 cattle were led to the truck which had 2 pens of equal size at the front and back ( 5 cattle in each pen). The stocking density was $1.5 \mathrm{~m}^{2} /$ cattle (one deck lorry with a surface area of $6.00 \mathrm{~m} \times 2.50 \mathrm{~m}=15 \mathrm{~m}^{2}$ ). The loading and unloading were timed and negative behavioral events were noted according to the scoring system of María et al. (2004).

According to season, cattle were divided into 4 groups of 240 animals each ( 120 bulls and 120 heifers). Cattle were transported from the farm to the slaughterhouse in winter (December to February), spring (March to May) summer (June to August) and autumn (September to November). Temperature and relative humidity data were collected twice a month - on the 
days of transport, during loading at the farm and during unloading at the slaughterhouse with a Kestrel 4000 Pocket Weather Tracker (Nielsen-Kellerman, Boothwyn, PA, USA).

The cattle were slaughtered according to the standard procedure, immediately after being unloaded. Carcasses were chilled under commercial conditions at $4{ }^{\circ} \mathrm{C}$ for $24 \mathrm{~h}$. On the following day, the concentration of hydrogen ions $(\mathrm{pH})$ was measured at $24 \mathrm{~h}$ post mortem with a Eutech CyberScan pH 310 instrument (Eutech Instruments Pte Ltd, Singapore). Measurements were made on the right side of $m$. longissimuss dorsi removed from the area between the 6 th and 7 th ribs. Electrical conductivity (EC) was measured $24 \mathrm{~h}$ after slaughter with a LF-Control System Instrument (Würthinger, Pettenbach, Austria) in miliSiemens per centimeter $(\mathrm{mS} / \mathrm{cm})$. Meat colours were measured at $24 \mathrm{~h}$ post mortem plus $80 \mathrm{~min}$ after bloom time ( $80 \mathrm{~min}$ after cutting, exposing $\mathrm{m}$. longissimuss dorsi to air). In order to evaluate the colour pattern, CIE (Commission International de l'Éclairage) 1976 values (L*: lightness, $a^{*}$ : redness, $b^{*}$ : yellowness, $c^{*}$ : chroma, $h$ : hue) were measured with a Minolta Chroma Meter CR-410 colorimeter (Minolta Co., Ltd., Japan), with a 50-mm-diameter measurement area using D65 illumination. Statistical analysis was carried out using the SAS General Linear Model procedures (SAS Institute Inc., Cary, NC, USA) with a fixed effect of sex, transport time and season. Mean separations were performed using the Tukey (HSD) multiple range test for significant main effect at $P<0.05$.

\section{Results and discussion}

Table 1

Environmental conditions, loading and unloading time and carcass traits of Simmentals breed per season

\begin{tabular}{lcccc}
\hline & \multicolumn{3}{c}{ Season } \\
& Winter & Spring & Summer & Autumn \\
\hline Environmental conditions & & & & \\
$\mathrm{Ta},{ }^{\circ} \mathrm{C}$ & $3.63^{\mathrm{a}}$ & $14.13^{\mathrm{b}}$ & $23.00^{\mathrm{c}}$ & $14.50^{\mathrm{b}}$ \\
$\mathrm{Td},{ }^{\circ} \mathrm{C}$ & $3.93^{\mathrm{a}}$ & $8.17^{\mathrm{b}}$ & $7.99^{\mathrm{b}}$ & $8.75^{\mathrm{b}}$ \\
$\mathrm{Tt},{ }^{\circ} \mathrm{C}$ & $3.29^{\mathrm{a}}$ & $6.79^{\mathrm{b}}$ & $6.96^{\mathrm{b}}$ & $4.50^{\mathrm{a}}$ \\
$\quad$ Relative humidity, \% & $78.58^{\mathrm{a}}$ & $67.38^{\mathrm{b}}$ & $62.54^{\mathrm{b}}$ & $80.04^{\mathrm{a}}$ \\
Loading and unloading time, minutes per animal & & & & \\
$\quad$ Loading time & 1.68 & 1.58 & 2.04 & 1.71 \\
Unloading time & 0.83 & 0.81 & 0.88 & 0.77 \\
Carcass traits & & & & \\
Warm carcass weight of bulls, kg & $357.26^{\mathrm{a}}$ & $362.33^{\mathrm{ab}}$ & $371.28^{\mathrm{b}}$ & $355.74^{\mathrm{a}}$ \\
Net weight gain of bulls, kg & $0.751^{\mathrm{a}}$ & $0.776^{\mathrm{ab}}$ & $0.794^{\mathrm{b}}$ & $0.758^{\mathrm{a}}$ \\
Bulls' age, months & 15.66 & 15.38 & 15.43 & 15.49 \\
Warm carcass weight of heifers, kg & 268.22 & 269.83 & 273.13 & 274.92 \\
Net weight gain of heifers, kg & 0.617 & 0.626 & 0.633 & 0.629 \\
Heifers' age, months & 14.31 & 14.22 & 14.24 & 14.41 \\
\hline
\end{tabular}

a,b,c different letters in the same row indicate significant difference $(P<0.05)$, Ta: average daily temperature, $\mathrm{Td}$ : difference between maximum and minimum daily temperatures according to the Croatian Metrological and Hydrological Service, Tt: difference between loading and unloading temperatures

As shown in Table 1, average daily temperatures $\mathrm{(Ta}$ ) in the winter season were significantly lower and those in the summer season significantly higher compared to other seasons $(P<0.05)$. Differences between maximum and minimum daily temperatures (Td) were 
significantly lower in the winter season than in other seasons. Differences between loading and unloading temperature ( $\mathrm{Tt}$ ) were significantly higher in the summer and spring seasons compared to the winter and autumn seasons. Average relative humidity was significantly higher in autumn and winter than in other seasons $(P<0.05)$. Loading and unloading times were not significantly different between different seasons and quite short with few negative behavioural events (falls and slips). According to the results of carcass traits, bulls slaughtered in summer had significantly higher warm carcass weight and net weight gain compared to bulls slaughtered in the winter and autumn seasons $(P<0.05)$. No significant differences were found between heifers slaughtered in different seasons.

The effects of sex and season on $\mathrm{pH}$, electrical conductivity and muscle colour are shown in Table 2. In the presented study, heifers had significantly lower muscle $\mathrm{pH}, \mathrm{EC}$ values and higher $\mathrm{L}^{*}$ and $\mathrm{b}^{*}$ values, while bulls had significantly higher $\mathrm{pH}, \mathrm{EC}$ and $\mathrm{a}^{*}$ values $(P<0.05)$. Our findings agree with Page et al. (2001) and Wulf \& Wise (1997), who also reported that bulls produced beef with higher $\mathrm{pH}$ values and lower $L^{*}$ and $b^{*}$ values. Tatum et al. (2007) maintained that the differences between sexes were associated with endogenous hormone levels, differences in temperament and reactions to pre-harvest stress. Gruber et al. (2006) found that cattle exhibiting calm behaviour immediately following transport had the lowest blood lactate levels, whereas behaviour of agitated cattle could have affected their $\mathrm{pH}$ values. In our study, heifers produced significantly lighter beef with lower electrical conductivity than bulls. Some authors (Voisinet et al. 1997, Wulf et al. 1997, Page et al. 2001, Tatum et al. 2007) found that heifers typically produced carcasses with higher marbling score, which affected the $L^{*}$ and $b^{*}$ values. Swantek et al. (1992) and Aldai et al. (2006) reported that animals with higher intramuscular fat content (marbling) had lower results for juice loss and electrical conductivity. In the presented study (Table 2), the groups of cattle slaughtered during the summer and winter periods had poorer $\mathrm{pH}, \mathrm{EC}$ and colour values compared to cattle slaughtered in spring and autumn. Significant differences in parameters $\mathrm{pH}, \mathrm{EC}$ and colour values were found between cattle slaughtered during the spring and summer seasons and between cattle slaughtered during the autumn and summer seasons $(P<0.05)$. Significant differences in parameters $\mathrm{pH}, \mathrm{b}^{*}$ and $\mathrm{h}^{*}(P<0.05)$ were found between cattle slaughtered in the spring and winter seasons. Comparison between the winter season and the summer season showed that significantly better values were obtained for parameters $\mathrm{pH}, \mathrm{EC}$ and colours $\left(\mathrm{a}^{*}, \mathrm{~b}^{*}, \mathrm{C}^{*}\right)$ in cattle slaughtered in the winter season $(P<0.05)$. There were no significant differences between cattle slaughtered in the winter and autumn seasons and between cattle slaughtered in the autumn and spring seasons. This result seems to indicate that meat colours differ in dependence on seasonal conditions. Our result is in agreement with several groups, who also found that the season had an adverse effect on beef quality (Baker 1981, Grandin 1996, Kladim et al. 2004, Mounier et al. 2006). In this study, bull beef had a significantly poorer colour, $\mathrm{pH}$ and EC values during the summer and winter seasons compared to the spring season $(P<0.05)$ and slightly poorer compared to autumn, whereas heifer beef had significantly poorer $\mathrm{pH}, \mathrm{EC}$ and colour $\left(\mathrm{a}^{*}, \mathrm{~b}^{*}, \mathrm{C}^{*}\right)$ values in the summer period compared to other seasons $(P<0.05)$. Similarly, Yong et al. (2003) reported that bull beef was significantly darker in summer and winter. Tarrant \& Sherington (1980) reported that October and December were the peak months for dark cutting beef. In contrast to this study, Fabiansson et al. (1984) found that the highest incidence of dark cutting beef was from May 
to August. Jones \& Tong (1989) reported that the frequency of dark cutting beef was higher in March and April and the lowest in December. Warriss (1992) concluded that the seasonal effect on beef quality was not large.

Table 2

Effect of season and sex on meat colour, $\mathrm{pH}$ and electrical conductivity ( $\mathrm{n}=120 /$ season)

\begin{tabular}{|c|c|c|c|c|}
\hline & Season & & & Mean ${ }^{2}$ \\
\hline & & Bulls & Heifers & \\
\hline $\mathrm{pH}$ & Winter & $5.60^{\mathrm{aA}}$ & $5.55^{\mathrm{bA}}$ & $5.58^{\mathrm{A}}$ \\
\hline & Spring & $5.56^{\mathrm{aB}}$ & $5.55^{\mathrm{aA}}$ & $5.55^{\mathrm{B}}$ \\
\hline & Summer & $5.60^{\mathrm{aA}}$ & $5.61^{\mathrm{aB}}$ & $5.61^{\mathrm{C}}$ \\
\hline & Autumn & $5.58^{\mathrm{aAB}}$ & $5.55^{\mathrm{bA}}$ & $5.56^{\mathrm{AB}}$ \\
\hline & Mean ${ }^{1}$ & $5.59^{\mathrm{a}}$ & $5.56^{\mathrm{b}}$ & \\
\hline EC & Winter & $7.17^{\mathrm{AA}}$ & $4.71^{\mathrm{bA}}$ & $5.94^{\mathrm{A}}$ \\
\hline & Spring & $7.52^{\mathrm{aB}}$ & $4.77^{\mathrm{bA}}$ & $6.15^{\mathrm{A}}$ \\
\hline & Summer & $7.07^{\mathrm{A}}$ & $4.34^{\mathrm{bB}}$ & $5.70^{\mathrm{B}}$ \\
\hline & Autumn & $7.32^{\mathrm{aAB}}$ & $4.78^{\mathrm{bA}}$ & $6.05^{\mathrm{A}}$ \\
\hline & Mean'1 & $7.27^{\mathrm{a}}$ & $4.65^{\mathrm{b}}$ & \\
\hline$L^{*}$ & Winter & $42.06^{\mathrm{aA}}$ & $43.89^{\mathrm{bA}}$ & $42.98^{A B}$ \\
\hline & Spring & $42.76^{\mathrm{aB}}$ & $43.93^{\mathrm{bA}}$ & $43.34^{B}$ \\
\hline & Summer & $41.99^{\mathrm{aA}}$ & $43.41^{\mathrm{bA}}$ & $42.70^{A}$ \\
\hline & Autumn & $42.42^{\mathrm{aAB}}$ & $43.88^{\mathrm{bA}}$ & $43.15^{\mathrm{B}}$ \\
\hline & Mean' & $42.31^{\mathrm{a}}$ & $43.78^{b}$ & \\
\hline$a^{*}$ & Winter & $29.19^{\mathrm{aA}}$ & $29.03^{\mathrm{aA}}$ & $29.11^{A}$ \\
\hline & Spring & $29.64^{\mathrm{aB}}$ & $28.96^{\mathrm{bA}}$ & $29.30^{A}$ \\
\hline & Summer & $29.11^{\mathrm{AA}}$ & $28.37^{\mathrm{bB}}$ & $28.74^{\mathrm{B}}$ \\
\hline & Autumn & $29.38^{\mathrm{aAB}}$ & $28.89^{\mathrm{bA}}$ & $29.13^{A}$ \\
\hline & Mean $^{1}$ & $29.33^{\mathrm{a}}$ & $28.81^{\mathrm{b}}$ & \\
\hline$b^{*}$ & Winter & $11.35^{\mathrm{aA}}$ & $11.89^{\mathrm{bA}}$ & $11.62^{A}$ \\
\hline & Spring & $11.77^{\mathrm{aB}}$ & $11.91^{\mathrm{aA}}$ & $11.84^{\mathrm{B}}$ \\
\hline & Summer & $11.32^{\mathrm{aA}}$ & $11.49^{\mathrm{aB}}$ & $11.40^{c}$ \\
\hline & Autumn & $11.57^{\mathrm{aAB}}$ & $11.88^{\mathrm{aA}}$ & $11.73^{\mathrm{AB}}$ \\
\hline & Mean' & $11.50^{\mathrm{a}}$ & $11.80^{\mathrm{b}}$ & \\
\hline$C^{*}$ & Winter & $31.33^{\mathrm{aA}}$ & $31.33^{\mathrm{aA}}$ & $31.33^{\mathrm{A}}$ \\
\hline & Spring & $31.91^{\mathrm{aB}}$ & $31.30^{\mathrm{bA}}$ & $31.60^{A}$ \\
\hline & Summer & $31.25^{\mathrm{aA}}$ & $30.61^{\mathrm{bB}}$ & $30.93^{\mathrm{B}}$ \\
\hline & Autumn & $31.59^{\mathrm{aAB}}$ & $31.24^{\mathrm{aA}}$ & $31.41^{\mathrm{A}}$ \\
\hline & Mean ${ }^{1}$ & $31.52^{\mathrm{a}}$ & $31.12^{\mathrm{b}}$ & \\
\hline$h^{*}$ & Winter & $21.20^{\mathrm{aA}}$ & $22.27^{\mathrm{bA}}$ & $21.74^{A C}$ \\
\hline & Spring & $21.63^{\mathrm{aB}}$ & $22.35^{\mathrm{bA}}$ & $21.99^{B}$ \\
\hline & Summer & $21.20^{\mathrm{aA}}$ & $22.02^{\mathrm{bA}}$ & $21.61^{c}$ \\
\hline & Autumn & $21.46^{\mathrm{aAB}}$ & $22.35^{\mathrm{bA}}$ & $21.90^{\mathrm{AB}}$ \\
\hline & Mean ${ }^{1}$ & $21.37^{\mathrm{a}}$ & $22.25^{\mathrm{b}}$ & \\
\hline
\end{tabular}

${ }^{1}$ mean of four seasons within the same sex $(n=480),{ }^{2}$ mean of two sex groups within the same season $(n=240)$, ${ }^{\mathrm{a}, \mathrm{b}}$ Different letters in the same row indicate significant difference $(P<0.05)$. ${ }^{\mathrm{A}, \mathrm{B}, \mathrm{C}}$ Different letters in the same column indicate significant difference $(P<0.05)$.

As shown in Table 3, transport time over the whole year had no significant influence on beef quality indicators in the studied sample. No significant influence of transport on beef quality was observed in some earlier research either (Fernandez et al. 1996, María et al. 2003). In this study, bulls transported for a shorter time had slightly poorer $\mathrm{pH}, \mathrm{L}^{*}, \mathrm{a}^{*}, \mathrm{~b}^{*}$ and 
$C^{*}$ values compared to bulls transported for a longer time. Heifers subjected to a shorter journey had slightly better $\mathrm{pH}, \mathrm{EC}, \mathrm{L}^{*}, \mathrm{~b}^{*}, \mathrm{C}^{*}$ and $\mathrm{h}^{*}$ values compared to heifers transported for a longer time. Jones et al. (1988) noted an insignificant adverse effect of transport time on beef quality. Villarroel et al. (2003) observed that longer journey, up to $6 \mathrm{~h}$, slightly increased $\mathrm{pH}$ and decreased colour parameters $\left(\mathrm{L}^{*}, \mathrm{a}^{*}, \mathrm{~b}^{*}\right)$. Some other studies found that longer journey significantly increased the $\mathrm{pH}$ value, and decreased colours (Poulanne \& Aalto 1981, Brown et al. 1990). Borell (2000) reports that transport is considered as a major stressor for farm animals and might have deleterious effects on health, well-being, performance and ultimately on product quality. Sanz et al. (1996) concluded that shorter journey gave animals less time to adapt to a new situation and animals arrived to the slaughterhouse with lower glycogen reserves, causing lower post-mortem rate of lactic acid synthesis, high ultimate $\mathrm{pH}$ and undesirable colour. In this study, significantly poorer $\mathrm{pH}$, EC and colour ( $\mathrm{L}^{*}$ and $\left.\mathrm{h}^{*}\right)$ values were observed during the summer season in groups of heifers transported for a longer time compared to heifers transported for a shorter time $(P<0.05)$. In groups of bulls subjected to a shorter journey from the farm to the slaughterhouse significantly poorer $\mathrm{pH}, \mathrm{EC}$ and colour parameters were observed during the winter period compared to bulls transported for a longer time $(P<0.05)$. Tarrant (1989) observed that due to colder temperatures, transport was more stressful in the winter season than transport in summer seasons. Grandin (1992) reported that the incidence of DFD was high during very cold weather combined with precipitation and during very warm weather or when large temperature fluctuations occurred over a short period of time. Murray (1989) reported that the mean incidence of dark meat was significantly affected by minimum and maximum daily temperatures. Mounier et al. (2006) found that the journey was physically demanding for bulls when the external temperature was above $18^{\circ} \mathrm{C}$. Morrison \& Lofgreen (1979) reported that temperature stress in cattle was observed when the air temperature was above $20.3^{\circ} \mathrm{C}$. Scanga et al. (1998) reported that when average temperatures were below $0^{\circ} \mathrm{C}, 2$ days to 1 day before harvest, incidence of DFD in heifers was higher $(P<0.05)$ than when temperatures were above $0^{\circ} \mathrm{C}$. During our survey, temperatures were high in summer $\left(23^{\circ} \mathrm{C}\right.$ on average, with peaks at $\left.29^{\circ} \mathrm{C}\right)$, while winter temperatures were low $\left(3.63^{\circ} \mathrm{C}\right.$ on average, with peaks at $\left.-12^{\circ} \mathrm{C}\right)$; hence we suppose that at external temperatures above $23^{\circ} \mathrm{C}$ and below $3{ }^{\circ} \mathrm{C}$ the journey was physically demanding for Simmental bulls and heifers, resulting in increased $\mathrm{pH}$ value and a decrease in colour parameters.

In conclusion, under optimal weather conditions during spring and autumn period transport time had slight effects on some physicochemical properties of beef quality. Under sub-optimal weather conditions during winter and summer period the effects of transport on some physicochemical properties of beef quality were higher. The study shows that preslaughter journey along with season conditions can have significant deleterious effects on some physicochemical beef quality traits. There is a need in the future to broaden research focus on truck equipment designed to reduce as much as possible the negative effects of extreme environmental conditions in terms of optimising cattle welfare and minimising losses in production yield and quality. What was left unexplored but deserves to be further pursued and evaluated is the effective temperature like temperature-humidity and wind chill index in order to more precisely determine cattle discomfort index. The results show that the effect of pre-slaughter acute stress should never be underestimated, since it can reduce beef quality in very short period of time. 
Table 3

Effect of transport time and season on pH, electrical conductivity and CIE colour values of Simmental bulls and heifers ( $n=60 /$ transport time/season)

\begin{tabular}{|c|c|c|c|c|c|c|c|}
\hline & Sex & Transport & & & & & Mean' \\
\hline & & & Winter & Spring & Summer & Autumn & \\
\hline $\mathrm{pH}$ & Bulls & Short journey & $5.63^{\mathrm{aA}}$ & $5.56^{\mathrm{bA}}$ & $5.59^{\mathrm{A}}$ & $5.57^{\mathrm{bc} A B}$ & $5.59^{A}$ \\
\hline & & Long journey & $5.57^{\mathrm{abB}}$ & $5.56^{\mathrm{bA}}$ & $5.61^{\mathrm{AB}}$ & $5.58^{\mathrm{abA}}$ & $5.58^{\mathrm{A}}$ \\
\hline & Heifers & Short journey & $5.56^{\mathrm{aB}}$ & $5.55^{\mathrm{aA}}$ & $5.59^{\mathrm{bA}}$ & $5.55^{\mathrm{aB}}$ & $5.56^{\mathrm{B}}$ \\
\hline & & Long journey & $5.56^{\mathrm{aB}}$ & $5.55^{\mathrm{aA}}$ & $5.63^{\mathrm{bB}}$ & $5.55^{\mathrm{aB}}$ & $5.57^{\mathrm{B}}$ \\
\hline EC & Bulls & Short journey & $6.97^{\mathrm{aA}}$ & $7.59^{\mathrm{bA}}$ & $7.19^{\mathrm{acA}}$ & $7.40^{\mathrm{bcA}}$ & $7.29^{A}$ \\
\hline & & Long journey & $7.37^{\mathrm{aB}}$ & $7.46^{\mathrm{aA}}$ & $6.95^{\mathrm{bA}}$ & $7.24^{\mathrm{abA}}$ & $7.25^{A}$ \\
\hline & Heifers & Short journey & $4.74^{\mathrm{ac}}$ & $4.79^{\mathrm{aB}}$ & $4.39^{\mathrm{bB}}$ & $4.78^{\mathrm{aB}}$ & $4.68^{\mathrm{B}}$ \\
\hline & & Long journey & $4.68^{\mathrm{ac}}$ & $4.76^{\mathrm{aB}}$ & $4.29^{\mathrm{bB}}$ & $4.78^{\mathrm{aB}}$ & $4.63^{\mathrm{B}}$ \\
\hline$L^{*}$ & Bulls & Short journey & $41.68^{\mathrm{aA}}$ & $42.79^{\mathrm{bA}}$ & $42.19^{\mathrm{acA}}$ & $42.56^{\mathrm{bcA}}$ & $42.30^{A}$ \\
\hline & & Long journey & $42.44^{\mathrm{aB}}$ & $42.73^{\mathrm{aA}}$ & $41.78^{\mathrm{bcA}}$ & $42.29^{\mathrm{acA}}$ & $42.31^{\mathrm{A}}$ \\
\hline & Heifers & Short journey & $43.87^{\mathrm{ac}}$ & $44.02^{\mathrm{aB}}$ & $43.71^{\mathrm{aB}}$ & $43.87^{\mathrm{aB}}$ & $43.87^{\mathrm{B}}$ \\
\hline & & Long journey & $43.91^{\mathrm{aC}}$ & $43.84^{\mathrm{aB}}$ & $43.12^{\mathrm{bc}}$ & $43.89^{\mathrm{aB}}$ & $43.69^{B}$ \\
\hline$a^{*}$ & Bulls & Short journey & $28.82^{\mathrm{aA}}$ & $29.70^{\mathrm{bA}}$ & $29.26^{\mathrm{CA}}$ & $29.42^{\mathrm{bcA}}$ & $29.30^{A}$ \\
\hline & & Long journey & $29.57^{\mathrm{aB}}$ & $29.58^{\mathrm{aA}}$ & $28.96^{\mathrm{bA}}$ & $29.34^{\mathrm{abA}}$ & $29.36^{A}$ \\
\hline & Heifers & Short journey & $28.99^{\mathrm{aA}}$ & $28.96^{\mathrm{aA}}$ & $28.45^{\mathrm{bB}}$ & $28.84^{\mathrm{abB}}$ & $28.81^{\mathrm{B}}$ \\
\hline & & Long journey & $29.06^{\mathrm{aA}}$ & $28.97^{\mathrm{aB}}$ & $28.28^{\mathrm{bB}}$ & $28.93^{\mathrm{aB}}$ & $28.81^{\mathrm{B}}$ \\
\hline$b^{*}$ & Bulls & Short journey & $11.11^{\mathrm{aA}}$ & $11.80^{\mathrm{bA}}$ & $11.44^{\mathrm{CA}}$ & $11.65^{\mathrm{bcAB}}$ & $11.50^{\mathrm{A}}$ \\
\hline & & Long journey & $11.60^{\mathrm{aB}}$ & $11.73^{\mathrm{aA}}$ & $11.20^{\mathrm{bA}}$ & $11.49^{\mathrm{abA}}$ & $11.51^{\mathrm{A}}$ \\
\hline & Heifers & Short journey & $11.87^{\mathrm{aB}}$ & $11.94^{\mathrm{aA}}$ & $11.62^{\mathrm{aA}}$ & $11.85^{\mathrm{aB}}$ & $11.82^{\mathrm{B}}$ \\
\hline & & Long journey & $11.92^{\mathrm{aB}}$ & $11.88^{\mathrm{aA}}$ & $11.36^{\mathrm{bA}}$ & $11.91^{\mathrm{aB}}$ & $11.77^{\mathrm{B}}$ \\
\hline $\mathrm{C}^{*}$ & Bulls & Short journey & $30.89^{\mathrm{aA}}$ & $31.95^{\mathrm{bA}}$ & $31.42^{\mathrm{cA}}$ & $31.66^{\mathrm{bcA}}$ & $31.48^{\mathrm{A}}$ \\
\hline & & Long journey & $31.76^{\mathrm{aB}}$ & $31.86^{\mathrm{aA}}$ & $31.07^{\mathrm{bA}}$ & $31.52^{\mathrm{aA}}$ & $31.55^{\mathrm{A}}$ \\
\hline & Heifers & Short journey & $31.33^{\mathrm{aA}}$ & $31.33^{\mathrm{aB}}$ & $30.73^{\mathrm{aAB}}$ & $31.18^{\mathrm{abA}}$ & $31.14^{\mathrm{B}}$ \\
\hline & & Long journey & $31.34^{\mathrm{aA}}$ & $31.28^{\mathrm{aB}}$ & $30.49^{\mathrm{bA}}$ & $31.29^{\mathrm{aA}}$ & $31.10^{\mathrm{B}}$ \\
\hline$h^{*}$ & Bulls & Short journey & $21.01^{\mathrm{aA}}$ & $21.66^{\mathrm{bA}}$ & $21.32^{\mathrm{abA}}$ & $21.56^{\mathrm{bA}}$ & $21.39^{A}$ \\
\hline & & Long journey & $21.40^{\mathrm{abB}}$ & $21.60^{\mathrm{aA}}$ & $21.08^{\mathrm{bA}}$ & $21.35^{\mathrm{abA}}$ & $21.36^{\mathrm{A}}$ \\
\hline & Heifers & Short journey & $22.26^{\mathrm{aC}}$ & $22.41^{\mathrm{aB}}$ & $22.19^{\mathrm{aB}}$ & $22.33^{\mathrm{aB}}$ & $22.30^{\mathrm{B}}$ \\
\hline & & Long journey & $22.29^{\mathrm{ac}}$ & $22.30^{\mathrm{aB}}$ & $21.84^{\mathrm{bc}}$ & $22.37^{\mathrm{aB}}$ & $22.20^{\mathrm{B}}$ \\
\hline
\end{tabular}

a,b,c, Different letters in the same row indicate significant difference $(P<0.05),{ }^{A, B}, C$ Different letters in the same column indicate significant difference $(P<0.05)$, ${ }^{1}$ mean of four seasons within the same sex and transport time $(n=240)$

\section{Acknowledgement}

This research was supported by PIK Vrbovec Company d.d. The authors thank V. Garašanin, D. Ardalić, I. Prka and D. Jambrać for technical support.

\section{References}

Agnes F, Sartorelli P, Borrow HA, Locatelli A (1990) Effect of transport loading or noise on blood biochemical variables in calves. J Vet Res 51, 1679-1681

Aldai N, Murray BE, Martinez A, Oliván M, Troy DJ, Osoro K, Nájera Al (2006) The influence of breed and mhgenotype on carcass conformation, meat physico-chemical characteristics, and fatty acid profile of muscle from yearling bulls. Meat Sci 72, 486-495 
Baker FH, Beck AM, Binkerd EF, Blosser TH, Brown KI, Corah LR, Curtis SE, Fox MW, Hahn GL, Johnson DE, Kearl WG, Kinsman DM, Lechtenberg VL, Marten GC, Montgomery MJ, Ohlendorf GW, Preston RL, Rice RW, Ringer RK, Robinson FR, Schneider NR, Ullrey DE, Willham RL, Young J (1981) Scientific aspects of the welfare of food animals. Council for Agricultural Science and Technology (CAST), Report 91. Ames, IA, USA, 54

Borell E (2000) Stress and coping in farm animals. Arch Tierz 43, Special Issue, 144-152

Broom D (2003) Transport stress in cattle and sheep with details of physiological, ethological and other indicators. Dtsch Tierarztl Wochenschr 110, 83-88

Brown SN, Bevis EA, Warriss PD (1990) An estimate of the incidence of dark cutting beef in the United Kingdom. Meat Sci 27, 249-258

Fabiansson S, Erichsen I, Reuterswärd AL, Malmfors G (1984) The incidence of dark cutting beef in Sweden. Meat Sci 10, 21-33

Fernandez X, Monin G, Culioli J, Legrand I, Quilichini Y (1996) Effect of duration of feed withdrawal and transportation time on muscle characteristics and quality in Friesian-Holstein calves. J Anim Sci 74, 15761583

Grandin T (1992) Problems with bruises and dark cutters in harvest steers/heifers. In: Smith GC, Savell JW, Clayton RP, Field TG, Griffin DB, Hale DS, Miller MF, Montgomery TH, Morgan JB, Tatum JD, Wise JW (eds.) Improving the Consistency and Competitiveness of Beef. A Blueprint for Total Quality Management in the Fed Beef Industry. The Final Report of the National Beef Quality Audit-1991. National Cattlemen's Association, Colorado State University, Fort Collins, CO, USA/Texas A\&M University, TX, USA

Grandin T (1996) Factors that impede animal movement at slaughter plants. J Am Vet Med Assoc 209, 757-759

Grandin T (1997) Assessment of stress during handling and transport. J Anim Sci 75, 249-257

Grandin T (2000) Behavioural principles of handling cattle and other grazing animals under extensive conditions. In: Grandin T (ed.) Livestock Handling and Transport, 2nd ed., CABI Publishing; Wallingford, Oxon, UK/New York, NY, USA, 63-86

Gruber SL, Tatum JD, Grandin T, Scanga KE, Smith GC (2006) Is the difference in tenderness commonly observed between heifers and steers attributable to differences in temperament and reaction to pre-harvest stress? Final report, submitted to the National Cattlemen's Beef Association. Department of Animal Sciences, Colorado State University, Fort Collins, CO, USA, 1-38

Hahn GL, Mader TL (1997) Heat waves in relation to thermoregulation, feeding behaviour and mortality of feedlot cattle. Am Soc Agric Eng 1, 563-571

Jones SDM, Schaefer AL, Tong AKW, Vincent BC (1988) The effects of fasting and transportation on beef cattle. 2. Body component changes, carcass composition and meat quality. Livest Prod Sci 20, 25-35

Jones SDM, Tong AKW (1989) Factor influencing the commercial incidence of dark cutting beef. Can J Anim Sci 69, 649-654

Kladim IT, Mahgoub O, Al-Ajmi DS, Al-Maqbaly RS, Al-Mugheiry SM, Bartolome DY (2004) The influence of season on quality characteristics of hot-boned beef $m$. Iongissimus thoracis. Meat Sci 66, 831-836

Lacourt A, Tarrant PV (1985) Glycogen depletion patterns in myofibres of cattle during stress. Meat Sci 15, $85-100$

Lister D (1988) Muscle metabolism and animal physiology in the dark cutting condition. In: Fabiansson SU, Shorthose WR, Warner RD (eds.) Dark-cutting in cattle and sheep. Proc. of an Australian workshop. Australian Meat and Livestock Research and Development Corporation, Sydney South, NSW, Australia,19-25

María GA, Villarroel M, Sanudo C, Olleta JL, Gebresenbet G (2003) Effect of transport time and ageing on aspects of beef quality. Meat Sci 65, 1335-1340

María GA, Villarroel M, Chacón G, Gebresenbet G (2004) Scoring system for evaluating the stress to cattle of commercial loading and unloading. Vet Rec 154, 818-821

Morrison SR, Lofgreen GP (1979) Beef cattle response to air temperature. Trans ASAE 22, 861-862

Mounier L, Dubroeucq H, Andanson S, Veissier I (2006) Variations in meat $\mathrm{pH}$ of beef bulls in relation to conditions of transfer to slaughter and previous history of the animals. J Anim Sci 84, 1567-1576 
Murray AC (1989) Factors affecting beef color at time of grading. Can J Anim Sci 69, 347

Page JK, Wulf DM, Schwotzer TR (2001) A survey of beef muscle color and pH. J Anim Sci 79, 678-687

Poulanne E, Aalto H (1981) The incidence of dark-cutting beef young bulls in Finland. Curr Top Vet Med 10, 462-475

Sanz MC, Verde MT, Saez T, Sanudo C (1996) Effect of breed on muscle glycogen and dark cutting incidence in stressed young bulls. Meat Sci 43, 37-42

Scanga JA, Belk KE, Tatum JD, Grandin T, Smith GC (1998) Factors contributing to the incidence of dark cutting beef. J Anim Sci 76, 2040-2047

Smith GC, Tatum JD, Morgan JB (1993) Dark cutting beef: physiology, biochemistry and occurrence. Colorado State University, Fort Collins, CO, USA

Swanson JC, Morrow-Tesch J (2001) Cattle transport: Historical, research and future perspectives. J Anim Sci 79, E-Suppl. 102-109

Swantek PM, Crenshaw JD, Marchello MJ, Lukaski HC (1992) Bioelectrical impedance: a nondestructive method to determine fat-free mass of live market swine and pork carcasses. J Anim Sci 70, 169-177

Tarrant PV, Sherington J (1980) An investigation of ultimate $\mathrm{pH}$ in the muscles of commercial beef carcasses. Meat Sci 4, 287-297

Tarrant PV (1989) Animal behaviour and environment in the dark-cutting condition in beef-a review. Ir J Food Sci Technol 13, 1-21

Tatum JD, Gruber SL, Schneider BA (2007): Pre-Harvest Factors Affecting Beef Tenderness in Heifers. Executive Summary. Department of Animal Science, Colorado State University, CO, USA, 1-18

Villarroel M, María G, Sañudo C, Sierra I, Garcla-Belenguer S, Gebresenbet G (2003) Critical points in the transport of cattle to slaughter in Spain that may compromise the animal's welfare. Vet Rec 149, 173-176

Voisinet BD, Grandin T, O'Connor SF, Tatum JD, Deesing MJ (1997) Bos Indicus-cross feedlot cattle with excitable temperaments have tougher meat and higher incidence of borderline dark cutters Meat Sci 46, 367-377

Warriss PD (1992) Animal welfare. Handling animals before slaughter and the consequence for welfare and product quality. Meat Focus Int 1, 135-138

Wulf DM, O'Connor SF, Tatum JD, Smith GC (1997) Using objective measures of muscle color to predict beef longissimus tenderness. J Anim Sci 75, 684-692

Yong SK, Seok KY, Young HS, Sung L (2003) Effect of season on color of Hanwoo (Korean native cattle) beef. Meat Sci 63, 509-513

Received 13 May 2011, accepted 13 September 2011.

Corresponding author:

Ante Ivanković

email: aivankovic@agr.hr

Department of Animal Production and Technology, Agricultural Faculty, University of Zagreb, Svetošimunska 25, 10000 Zagreb, Croatia 